\title{
Multi-vector Management of Soft Power Policies: Will Russian Soft Power Be Victimized by the Moscow-Erdogan Association?
}

\author{
C. Melakopides \\ University of Cyprus \\ CY-1678, Nicosia, Cyprus, 20537
}

\begin{abstract}
This article analyzes the potential impact of Turkey's foreign policy on Russia's soft power in several regions of the world. The author believes that the policy of President R.T. Erdogan in the Mediterranean, the Middle East and the Aegean Sea can cause significant damage to the image and international prestige of Moscow. The article argues that Russian policy should minimize the "toxic" impact of R.T. Erdogan's foreign policy on Russia's soft power in the considered regions.
\end{abstract} Cyprus

Keywords: R.T. Erdogan, Turkey, soft power, foreign policy, Russia, the Republic of

\section{Introduction}

The Russian Federation is cultivating energetically its Soft Power, especially during the current cynical and labyrinthine phase of international relations. Recent results, however, appear to be mixed. For instance, in a 2019 essay, an Israeli analyst argued that "Russian soft power efforts in the Middle East are bearing fruit, as many young Arabs now view Moscow as an ally and the US as unreliable" [1]. But the "SOFTPOWER 30" Index, for 2019, places Russia 30th among 30 states, below even Turkey's 29th score [2].

With "Russophobia" presently affecting Moscow-Washington and MoscowEU relations, Moscow is struggling to undermine unscrupulous anti-Russian propaganda. Simultaneously, however, Russian foreign policy is cultivating a sui generis "multiple embrace" with Erdogan's Turkey, whose international image is deeply traumatized, as demonstrated by the galloping international condemnation of Erdogan's domestic sins and his outlandish geopolitics. It seems to follow that Russia should also "contain" its own "Turkey problem", since President Erdogan's errors and crimes could damage by implication Moscow's image and international prestige.

This essay, then, will survey Erdogan's characteristic foreign policy decisions, actions, and "claims" in the Mediterranean, the Middle East and the 
Aegean Sea. Particular emphasis will be placed on Ankara's obsessive aggressiveness against Cyprus and Greece through Erdogan's endless military threats and legal and factual distortions. Such behavior against Moscow's two traditionally "special" friends needs to be exposed: first, because Ankara's foreign policy poses as different from what it really is; second, in order to show the banality of fake news and fake analyses generated by skillful Turkish propaganda; third, because the developing Russia-Turkey association keeps antagonizing the special Russia-Greece and Russia-Cyprus affinities and bonds; and finally, because Moscow is uniquely placed to minimize the toxic effects of Erdogan's adventurism on Russia's Soft Power.

\section{Erdogan's Goals and Means in the Eastern Mediterranean, the Middle East, and the Aegean Sea}

President Erdogan's belligerent regional adventures are driven by his professed ambition to establish the "New" or "Great Turkey" and reach "the Borders of his Heart" [3]. Ankara's inevitable militarism is then coupled with cunning rhetorical devices to cover up illegal expansionism. Echoing the neo-Ottoman syllogistic of Dr. Ahmet Davutoglu [4], Erdogan regularly asserts inter alia that Turkey, "victimized" by the 1923 Lausanne Treaty, "deserves" to regain its former (Ottoman) possessions. Thus, he has rationalized as legitimate targets vast areas of today's Syria, Iraq, Greece, its Aegean Islands, Cyprus, and lately Libya.

Erdogan's ongoing military aggression in Northern Syria, Northern Iraq, the Exclusive Economic Zone of the Republic of Cyprus and Libya should be called by their proper name: that is, clear invasions. Therefore, it is quite distressing that Ankara tries to deceive the Turkish people and the entire world by presenting all its illegal actions as "in accordance with International Law".

Simultaneously, Ankara's officials and spokespersons have adopted another uniquely Turkish formulation: they make their territorial "claims" in terms of Turkey's "rights and interests". Therefore, by conflating two distinct concepts, they aim to extract "rights" even from artificially conceived chauvinistic interests. "Rights", of course, should be premised on solid legal grounds; subjectively defined interests are alien to International Law. And yet, Erdogan and his close associates (defense minister Hulusi Akar, foreign minister Mevlut Cavusoglu, and spokesman Hami Aksoi) unexceptionally adopt the language of "rights and interests", especially when pursuing their latest ambitions in what they name "Blue Homeland".

This neologism, by sheer Turkish Diktat, covers a vast Eastern Mediterranean area engulfing half the Aegean Sea, "appropriating" all the Greek Islands of the Eastern Aegean, eliminating the entire Exclusive Economic Zone of Cyprus and part of the EEZ of the Dodecanese Islands and Crete. So, what are the alleged "grounds" for such claims? Turkey replies that "according to International Law", Islands do not have either Continental Shelf or an Exclusive Economic Zone.

This claim, of course, is demonstrably absurd: for it contradicts the 1982 United Nations Conference on the Law of the Sea (UNCLOS), which states (Article 121): 
1. An Island is a naturally formed area of land, surrounded by water, which is above water at high tide.

2. Except as provided in paragraph 3, the territorial sea, the contiguous zone, the exclusive economic zone and the continental shelf of an island are determined in accordance with the provisions of this Convention applicable to another land territory.

3. Rocks which cannot sustain human habitation or economic life of their own shall have no exclusive economic zone or continental shelf.

Therefore, Article 121.2 explains why Turkey refuses to sign UNCLOS and tries to substitute gunboat diplomacy for International Law. To be sure, Ankara occasionally states that, after all, it is not a signatory of the 1982 law. The UNCLOS, however, is part of International Customary Law, ratified by 167 states and by the European Union (EU), which Turkey hopes to join. Thus, the undisputed legitimation of Article 121 has led to the massive condemnations of Ankara's associated provocations.

Greek FM Nikos Dendias once quipped that Turkey's "legal" assertions are "neo-surrealist" (apparently linking "surrealism" and the "neo" of neoOttomanism). But Erdogan's baseless conception of "international law" about Islands has been obstinately extended further to one of two "MoUs" with Libya's GNA government in Tripoli. The memorandum allegedly delineating a TurkeyLibya EEZ presupposes the elimination of the sovereign rights of numerous Greek islands, including Rhodes and Crete, by abolishing their Continental Shelf and EEZ. That is why the EU has formally and repeatedly deplored this memorandum's illegality. Athens and Nicosia have rejected both memoranda as "null and void". Washington has variously expressed its condemnation calling them "provocative and counterproductive" [5].

Egypt's own condemnation, submitted to the Security Council on 19 December 2019, was premised on (1) the crucial Legal fact that Libya's "House of Representatives has not endorsed the two memorandums of understanding with Turkey" and (2) the facts of Geography [6]:

The maritime deal would give Turkey access to an economic zone across the Mediterranean, over the objections of Greece, Cyprus, and Egypt, which lie between Tukey and Libya geographically.

A week earlier, Russian Ambassador to Athens, Andrey Maslov, commented on various issues during an annual press briefing [7]: "Speaking on bilateral relations, Maslov said, Greece is a traditional and reliable partner for Russia in Europe, and the two countries can continue building their relations 'even under the anti-Russian situation of sanctions' by the EU'. He also expressed appreciation for "the established stance of the Greeks, that the architecture of security in Europe must include Russia as well". And when asked about the recent Turkey-Libya memorandum on maritime zones, "the ambassador said [...] that 'the main issue is to observe the principles of international law, including the Lausanne Treaty of 1923 and the UN Convention on the Law of the Sea of 1982'.

More recently, given the mounting Libya crisis, Ambassador Maslov condemned Turkey quite explicitly, by declaring [8]: 
Islands do have a continental shelf and Exclusive Economic Zone (EEZ) in face of Turkey's insistence that they do not.

Erdogan's manifold illegality in Libya infuriated French President Emmanuel Macron, who erupted publicly. Prompted by both Turkey's pouring illegally weapons and jihadists to assist the Tripoli government, and by Ankara's hostile actions against the French frigate, Macron declared "the historical and criminal responsibility" of Turkey [9].

Finally, Greek FM Nikos Dendias, campaigning against the Erdogan-Sarraj memoranda, visited the President of the (elected) Libyan House of Representatives, Aguila Saleh, on 1 July 2020. In his published FM Statement, Mr. Dendias declared the identity of their positions and then added a potentially historic prospect [10]:

We also talked about the delimitation of maritime zones between Greece and Libya, not in the framework of illegality, as is the case with the so-called SarrajTurkey memorandum, but in the framework of International Law and follow-up to the relevant talks held between Greece and Libya in 2010.

Despite such international outcry, Erdogan and his ministers, through unending surrealistic statements and theatrical TV presentations, insist ad nauseam that they are acting "according to international law". Moreover, whenever Greece and Cyprus protest against Ankara's behavior, the latter dismisses them as "not knowing their place in the world". Therefore, banal verbal provocations accompany Turkey's blatant aggression adding insult to injury. Furthermore, since these violations of International Law and International Ethics are being progressively amassed, they entail three toxic consequences: first, Erdogan has become selfimprisoned in his untenable claims; second, the anti-Hellenic brainwashing of the Turkish people is sustained through the Erdogan-appropriated, servile, Turkish Media; and third, Erdogan's hostile rhetoric is endorsed by the Turkish Opposition who, in chauvinistic competition, frequently become more "Erdoganian" than Erdogan himself.

\section{Recent Escalating Aggression Against Cyprus and Greece}

Until very recently, Greece and Cyprus have insisted on dispute-resolution according to International Law, opting for friendship and cooperation with Ankara and the Turkish people. Nicosia and Athens, however, today realize that appeasing Turkey had proved utterly unwise and counterproductive: Erdogan's and his associates' offensive rhetoric, explicit anti-Hellenic threats, and absurd historical and legal distortions kept escalating as some examples suffice to demonstrate [11].

In January 2018, Erdogan's close adviser, Yigit Bulut, after asserting his "certainty" that Washington plans to make Greece attack Turkey, declared that, since Greece "is no match for Turkey's might", it would be "like a fly picking a fight with a giant" [12]. Moreover, referring to the (Greek) Imia islets that Turkey is trying to usurp, Bulut stated:

We will break the arms and legs of any officers, the Prime Minister, or of any minister, who dares to step onto Imia in the Aegean [12]. 
Also, in 2018, when some fascists burned a Turkish flag in Athens, Mustafa Deztiji, Erdogan's political ally, declared, "The Turkish flag one day will fly again in Athens" [13].

In March 2018, Erdogan pompously announced his macabre conception of creating the "Great Turkey" [14]: "Certainly, we will build a great and dynamic future for Turkey, and for this, we will sacrifice our life and take the lives of others when needed".

That such rhetorical delirium was not isolated or temporary was shown recently by distinguished Turkish columnist, Burak Bekdil, who commented on the May 2020 celebrations of Constantinople's 1453 conquest. Since Erdogan commemorated the conquest personally with Islamic prayers at the Haghia Sophia, arguably Christianity's holiest monument, Bekdil wrote inter alia [15]:

In Turkish jargon...it is "conquest" when we do it and "invasion" when others do it. In this year's celebrations, President Recep Tayyip Erdogan raised the stakes when he spoke of the conquest prospectively, not just retrospectively. "I wish that God grant this nation many more happy conquests", he said at a celebration where he recited from the Quran.

In all this typically Turkish "conquest" fanfare, a serious question remains to be asked: "When Erdogan wished God to grant Turkey many more happy conquests, which non-Turkish lands is he hoping to 'conquer'?".

Manifestly, Erdogan's and his close associates' perennial verbal abuse is central to psychological warfare or "hybrid war" that aims to offend and provoke. Hellenism simultaneously experiences Turkey's deep hostility by palpably illegal actions, that essentially aim to revise the status quo, by dragging the two states to "negotiations" under Turkey's self-serving conditions. Thus, let us recall the daily violations of Greek airspace in the Aegean Sea and the Athens Freedom of Information Region (FIR) by armed Turkish military jets; almost daily flights by Turkish military jets over Eastern Aegean Greek islands, often a few hundred meters above the terrified inhabitants; the constant issue of illegitimate NAVTEX within the Cypriot EEZ, long aiming to cancel Nicosia's hydrocarbon program; the actual cancellation of gas drilling in Bloc 3 of the Cypriot EEZ by the Turkish Navy in March 2018, violating Nicosia's contract with Italian company ENI; and the February 2018 deliberate crash of a Turkish coast guard vessel into a Greek patrol boat off Imia, that literally threatened Greek sailors' lives.

In 2019, Ankara intensified its "third invasion" within the Cypriot EEZ, sending new drilling ships always accompanied by the Turkish Navy. The EU Institutions and individual Member-States flatly condemned these actions. Official Russian voices keep denouncing Ankara's relevant behavior since 2011, and Russian Ambassador Stanislav Osadchiy regularly declares that Moscow recognizes Cyprus' sovereign rights in its EEZ. Ambassador Tasos Tzonis received further assurances in October 2019 when he met Deputy Foreign Minister Alexander Grushko: "Full Russian support for the Republic of Cyprus' sovereign rights in its sea zones during Tzionis' discussions in Moscow" [16].

And yet, all these statements remain unaccompanied by any substantial sanctions against Turkey. Hence Erdogan remains unmoved, perceiving the lasting 
international passivity as license to continue. Simultaneously, by blackmailing the EU through the threat to "flood" it with migrants and "Syrian refugees", he keeps violating with impunity fundamental principles and norms of International Law.

\section{The Evros River Crisis}

In early 2020, the world community was shocked by the Evros River Crisis, at the northern Greece-Turkey border. During a late February Greek holiday, a "hybrid invasion" of Greece was attempted by thousands of people, misguided by Ankara into believing that "Turkey's borders with Europe are now open". In reality, Erdogan had opened Turkey's border to Greece when Athens had declared it closed. For Greece has been unable to host any more than the myriads of people that Turkey has forced it to accept on the Aegean Islands and mainland Greece. Moreover, the overwhelming majority were neither "refugees from Syria" nor even "refugees", being mainly economic migrants: primarily from Pakistan, Afghanistan, and even North Africa. As it transpired, they included former prisoners in Turkish prisons and real jihadists from Syria.

What is happening here is a textbook case for destabilizing entire regions. The situation is similar to the pre-Balkan crisis in Kosovo. Erdogan's movements follow the same patterns as the ones that preceded his intervention in Syria, when he used the populations expelled from there as weapons and an alibi [17].

In addition to "weaponizing" thousands of miserable people threatening to destabilize Greece and the EU to extract pro-Turkey decisions - including more money and support for its Syria adventures - Ankara aggravated the Crisis by orchestrating a campaign of fake news and vicious propaganda. Immature Western journalists, passionate Turkish propagandists, and some naïve Western academics were deceived by Turkey's fabricated news and unethical misinformation, endangering Greece's dignity and prestige.

The EU's top leadership, however, set the record straight. It gave Greece unreserved support during the visit to Evros River by European Commission President Ursula von der Leiden, European Council President Charles Michel, European Parliament President David-Maria Sassoli, and Croatian Prime Minister Andrej Plenkovic. They were escorted by Greek PM Kyriakos Mitsotakis, who said that "Turkey has now become an 'official migrant smuggler'". The EU leaders added [18]:

It is no longer a refugee-migration problem but an 'asymmetric threat' to Greece's eastern border, which is also Europe's border.

Ankara's crude psychological warfare included the Interior Minister's unashamed lie that "117,677 refugees have crossed into Greece" (ibid.). In fact, as EURAKTIV's Balkan expert, Georgi Gotev, explained in detail [18]: "the total number of migrants gathered in the border areas is estimated at some 20,000"; that the Greek authorities said that fewer than 200 migrants have managed to cross the border; and that "Greece has already sentenced all of them to four years of jail for illegal crossing".

Therefore, the Evros tragedy turned into Erdogan's and his regime's profound international embarrassment. Greece expanded its measures to protect its and 
Europe's borders from further (threatened) "hybrid warfare". But this Crisis had another unintended consequence: the effective response by Greece's political leadership and its security forces was perceived by the Greek people as a victory against the aggressor, raising thereby their self-confidence and pride. And while Greece attracted the respect of foreign political elites and honest commentators, the notorious pro-Erdogan Daily Sabah continued its constant anti-Hellenic hatespeech: far from describing the Crisis as Ankara's "migrant smuggling", it chose the following dishonest formulation [19]:

Ankara recently announced that it would no longer try to stop asylum-seekers, refugees, and migrants from crossing into Europe. Thousands have since flocked to Turkey's Edirne province, which borders Greece and Bulgaria to make their way into Europe.

Daily Sabah knew very well that no one could "make their way into Europe" both because Greece had closed its border and because no neighbors had opened theirs. Moreover, the paper's immoral text used insulting statements by a certain "refugee rights researcher" and "advocate at Human Rights Watch", who claimed that the Greek security forces had "detained, assaulted, sexually assaulted, robbed, and stripped asylum-seekers and migrants". This fabrication was totally falsified by independent reporters and commentators; by the aforementioned top EU officials; and by the European Border and Coast Guard Agency (FRONTEX). Therefore, one should note Michael Rubin's 1 April 2020 commentary, entitled "Human Rights Watch reports are no longer credible" [20].

The Evros case illustrates dramatically Ankara's ruses, sheer lies, stratagems, and other deceptive practices deployed in the Eastern Mediterranean, the Cypriot EEZ, the Aegean Sea, Syria, Iraq, and now Libya, in order to implement Erdogan's megalomania [21]. What deserves a separate treatment is why Erdogan is fixated on Hellenism, verbally abusing and threatening it militarily unless Cyprus and Greece yield to his blackmail.

For now, the following hypotheses seem irresistible: (1) Turkey's anti-Hellenic geopolitical bulimia erupted in the 1970s when oil reserves were discovered in the northern Aegean and Ankara decided to demand half of the Greek Continental Shelf; (2) the "Blue Homeland" consists primarily of Greek territories and Greece's threatened sovereign rights; (3) Turkey had always regarded Greece as far weaker than Turkey and weaker than what Greece really is; (4) Turkey cannot forgive Cyprus and Greece for their EEZs' hydrocarbon deposits in contrast to missing its own; (5) Erdogan cannot "tolerate" that Hellenism has weaved substantial collaboration with neighboring Egypt, Israel, Jordan, and Lebanon; increasingly with France; and probably with (hesitating) Italy; and (6) Turkish theologian, Cemil Kilic, asked about Erdogan's passion for turning Aghia Sophia into a mosque, admitted inter alia Turkey's "sense of inferiority vis-à-vis the West" [21].

\section{Conclusion}

In my recent book on Russia-Cyprus relations and in five essays for the Russian International Affairs Council (2017-2019) [22], I have celebrated Russia's 
special bonds with Hellenism, founded on mutual interests, shared values, historical/cultural and "spiritual" affinities, and respect for International Law. More recently, I recognized some unease and mutual complaints in Russia-Cyprus relations, emanating primarily from the Moscow-Ankara "multiple embrace". Progressively, however, Erdogan's "sui generis personality" (to put it euphemistically) and his geopolitical megalomania have disfigured Russia-Turkey relations: besides concurrence, they also exhibit contradictory perceptions, interests, rights, and suspicions, manifested primarily in Syria and Libya.

Moreover, Erdogan's opportunism, adventurism, and overextension show today signs of despair, since amateurish decisions have traumatized Turkey's economy while blatantly illegal and unethical actions have isolated Turkey. Therefore, while it may not be now a "pariah state", it is no longer an "ordinary country". As for the EU's prolonged inaction toward Erdogan's aggressiveness especially against full Member-States Cyprus and Greece - it was primarily caused by his prolonged bullying, constant blackmail, and the colossal economic interests of some EU countries. Today, however, there are clear signs that the EU began perceiving an emerging Turkish threat against Europe itself.

Indeed, in summer 2020, after President Macron's aforementioned eruption, Angela Merkel's seeming exhaustion, the threat of an Egypt-Turkey military confrontation, Josep Borrel's failed peace-making trip to Ankara, Turkey's unending exhibition of arrogant Realpolitik cum Machtpolitik, the despicable transformation of Aghia Sophia into a mosque, as well as the bombing of Turkeysupported targets in Libya's al-Watiya [23], the EU seems to be changing its mind, preparing substantial sanctions versus Turkey. After all, Erdogan's Libya invasion has attracted such international condemnation - by France, Egypt, UAE, Saudi Arabia, Syria, Israel, Cyprus, Greece, and Russia - amounting to Turkey's nearhumiliation, sufficient to miss the next "SOFT POWER 30".

It seems to follow, therefore, that Russian Soft Power is being victimized by implication by the Erdogan association. Hence Moscow, uniquely capable of containing its trouble-making associate, is ideally placed to take appropriate initiatives: as a principled service to international stability and international dignity, and to Russia's own international image and prestige.

\section{REFERENCES}

[1] Attias Sh. Russian Soft Power in the Middle East. BESA Center Perspectives Paper No. 1, 238. 26.06.2019.

[2] The Soft Power 30. URL: https://softpower30.com Accessed: 08.06.2020.

[3] Kostidis M. Erdogan Spoke about the Borders of His Heart. IBNA. 27.10.2016. URL: www.balkaneu.com/erogan-spoke-borders-heart. Accessed: 08.06.2020.

[4] Davutoglu A. Strategic Depth. Athens: Piotita; 2010 (In Gr.).

[5] Ignatiou M. Washington Supports Greece Against the Illegal Turkey-Tripoli Memorandum: 'It Is Provocative'. Hellas Journal. 05.06.2020. URL: www.hellasjournal.com/2020/06/1-ouasigton-tassete-iper-tis-ellads-gia-to-paranomo-mnimonio. Accessed: 08.06.2020 (In Gr.). 
[6] Lederer E. Egypt Rejects Turkey-Libya Sea Rights, Security Agreements. AP news. 20.12.2019. URL: www.apnews.com/77df1a4d5d17b5bd3b5fdc379db2718f. Accessed: 08.06.2020.

[7] Russian Envoy: Law of the Sea Should Be Respected. Kathimerini. 12.12.2019. URL: www.kathimerini.com/247469/article/ekathimerini/news/russian-envoy-law-of-thesea. Accessed: 08.06.2020.

[8] Russia Confirms It Backs Greece's View of Maritime Law-Greek City Times. Greek City. 15.06.2020. URL: www.greekcititi.com/2020/06/15/russia-confirms-itbacks-greeces-view-of-maritime-law. Accessed: 08.06.2020.

[9] Macron's New Shots Against Turkey: Its Responsibility in Libya Is "Historic and Criminal". Ethnos. 30.06.2020. URL: www.ethnos.gr/kosmos/112977_nea-pyra-makron-kata-toyrkias-istoriki-kai-egklimatiki-i. Accessed: 08.06.2020 (In Gr.).

[10] Statement of the Minister of Foreign Affairs, Nikos Dendias, following his meeting with the President of the Libyan House of Representatives, Aguila Saleh (Libya, 1 July 2020). URL: www.mfa.gr/index 2 .php?option=comcontent\&task=view\&id=27111\&1 temid=322\&pro. Accessed: 08.06.2020.

[11] Melakopides C. Brief Remarks on President R.T. Erdogan and His Allies' Methodical Use of Logical Fallacies. RUDN Journal of Political Science. 2018; 20 (3): 376-386.

[12] Erdogan Advisor Says Greece "Like a Fly Picking a Fight with a Giant". Ekathimerini. 14.02.2018. URL: www.ekathimerini.com/225825/article/kathimerini/news/Erdoganadvisor. Accessed: 08.06.2020.

[13] Delirium by Deztiji: The Turkish Flag Will Fly Back in Athens. On Alert. www.onalert.gr/paralhrhma-destdji-tourkikh-shmaia. Accessed: 08.06.2020 (In Gr.).

[14] "We Will Take the Life of Others for the Great Turkey". Militaire. 24.03.2018. URL: www.militaire.gr. Accessed: 08.06.2020 (In Gr.).

[15] Bekdil B. Turkey: Erdogan Wishes "Many More Happy Conquests". Gatestone Institute. 20.06.2020. URL: https://www.gatestoneinstitute.org/16092/turkey-erdogan-conquests. Accessed: 08.06.2020.

[16] Cyprus News Agency. 15.10.2019.

[17] Any Country Would Act Like Greece. Cyprus Mail. 05.03.2020.

[18] EU Leaders Tell Erdogan Europe Will Stay United, to His Disappointment. Euraktiv. 03.03.2020. URL: www.euraktiv.com/section/justice-home-affairs/news/eu-leaderstell-erdogan-europe-will. Accessed: 08.06.2020.

[19] EU Ignores Greece's Human Rights Abuses instead of Helping Asylum-seekers, Refugees. Daily Sabah. 17.03.2020. URL: www.dailysabah.com/politics/eu-ignoresgreeces-human-rights-abuses-instead-of-helping. Accessed: 08.06.2020.

[20] Rubin M. Human Rights Watch Reports Are No Longer Credible. Washington Examiner. 01.04.2020. URL: www.aei.org/op-eds/human-rights-watch-reports-are-nolonger-credible. Accessed: 08.06.2020.

[21] Turkey: Well-known Theologian Reveals What Is Behind Erdogan's Fixation with Aghia Sophia. Naftemboriki. 02.07.2020. URL: www.naftemboriki.gr/printStory/1615242. Accessed: 08.06.2020 (In Gr.).

[22] Melakopides C. Russia-Cyprus Relations: A Pragmatic-Idealist Perspective. London: Palgrave Macmillan; 2016. 211 p.

[23] Guesmi J. Rafale Attacks on Turkish Targets in Al-Watiya Airbase: Egyptian or French? The Arab Weakly. 06.07.2020. URL: www.thearabweakly.com/rafale-attacksturkish-targets-al-watiya-airbase-egyptian-or-french. Accessed: 08.06.2020.

\section{Article history:}

The article was submitted on 10.06.2020.

The article was accepted on 01.09.2020. 
Научная статья

\title{
Разновекторное управление политикой мягкой силы: как отразится на мягкой силе России сотрудничество с Р.Т. Эрдоганом?
}

\author{
К. Мелакопидес \\ Университет Кипра \\ СУ-1678, Никосия, Республика Кипр, 20537
}

Аннотация. Представленная статья анализирует потенциальное влияние внешней политики Турции на мягкую силу России в ряде регионов мира. Автор полагает, что политика Президента Р.Т. Эрдогана в Средиземноморье, на Ближнем Востоке и в Эгейском море может нанести значительный ущерб имиджу и международному престижу Москвы. В статье утверждается, что российская политика должна минимизировать «токсичное» воздействие внешней политики Р.Т. Эрдогана на мягкую силу России в рассматриваемом регионе.

Ключевые слова: Р.Т. Эрдоган, Турция, мягкая сила, внешняя политика, Россия, Республика Кипр

\section{История статьи:}

Статья поступила в редакцию: 10.06.2020.

Статья принята к публикации: 01.09.2020.

\section{Сведения об авторе:}

Костас Мелакопидес - PhD политологии, ассоциированный профессор факультета социальных и политических наук Университета Кипра (Республика Кипр) (e-mail: comel@ucy.ac.cy).

\section{Information about the author:}

Costas Melakopides - PhD, Associate Professor (ret.) of the Department of Social and Political Sciences, University of Cyprus (Republic of Cyprus) (e-mail: comel@ucy.ac.cy).

\section{Для цитирования:}

Melakopides C. Multi-vector Management of Soft Power Policies: Will Russian Soft Power Be Victimized by the Moscow-Erdogan Association? // Вестник Российского университета дружбы народов. Серия: Государственное и муниципальное управление. 2020. T. 7. № 4. C. 361-370. DOI: 10.22363/2312-8313-2020-7-4-361-370

\section{For citation:}

Melakopides C. Multi-vector Management of Soft Power Policies: Will Russian Soft Power be Victimized by the Moscow-Erdogan Association? RUDN Journal of Public Administration. 2020; 7 (4): 361-370. DOI: 10.22363/2312-8313-2020-7-4-361-370 